\title{
Bihari muinasjuttudest
}

\author{
Sarita Sahay
}

Folkloor nagu ka muud kunstiliste püüdluste saadused on loovuse manifestatsioon. Folkloor iseenesest hõlmab müüte, muistendeid, muinasjutte, ballaade, mõistatusi, vanasõnu ja usunditeateid (Dundes 1989). Terminit folkloor kasutas esmakordselt William J. Thoms 1846. aastal. Samamoodi kui teisedki kultuurielemendid ei ole folkloor pelgalt juhuse looming. Folkloor eksisteerib ajas ja ruumis ning ilmneb inimeste keelelistes ja sotsiaalsetes kontaktides, ta püsib pikka aega, muutudes käibimise jooksul (Thompson 1946).

Muinasjutt on üks tähtsamaid rahvaluule alaliike, mis on isegi tänapäeval suurele osale maailmast üks peamisi meelelahutuse ja eneseharimise vorme. Näiteks Indias jutustavad miljonid inimesed neid nii lõbu pärast kui esteetilistel kaalutlustel. Rahvajutte antakse suusõnaliselt edasi põlvest põlve, ent viimasel ajal on kasvanud ka kirjaliku edasiandmise osakaal. Muinasjuttudele omase fantaasiaküllase tausta kõrval on iseloomulik jutu lõpumoraal, millele tavaliselt pearõhk asetataksegi.

Erinevate regioonide rahvajutud esindavad sealsete inimeste mõtteid, arusaamu, traditsioone, käitumisviisi ja kombeid, aga sisaldavad ka vaimukusi ja elutarkust. Peale meelelahutuse pakuvad nad võimalust heita pilku päritolupaiga praegustele ja endistele kommetele ja pärimusele.

Biharil, mis on üks India tähtsamaid osariike, on rikkalik rahvakultuur. Kuulsa Pantshtantra lood pärinevad Pataliputra (Patna on Bihari pealinn) printsidelt. Biharis teatakse palju ballaade ja rahvalaule, mida esitatakse erinevail puhkudel, andmaks tööle hoogu ning rikastamaks puhkusehetki; vanasõnad ja mõistatused väljendavad elutarkust.

\section{Muinasjuttude tüpoloogia}

Jutud keerlevad enamasti üleloomulike, mütoloogiliste, pühenduslike, ajalooliste ja sotsiaalsete teemade ümber (Chettiar 1973). Füüsilised ja vaimsed ilmutused, kurjade vaimude lepitamine, hirmutavad olukorrad, kuradid ja kurjad vaimud, inimohverdused ja teised kummalised seigad on muinasjuttude kõige tavalisemad elemendid.

Bihari muinasjuttude sagedasemad motiivid ja tegelased on:

- üleloomulik vastane (nt draakon või hobuse ja papagoi ristand);

- maagia ja maagilised esemed (nt nähtamatuks tegev sõrmus, rääkiv merikarp, lendav

vaip, vaenlast nuhtlev kepp, võlulamp);

- ebatavalised võimed (nt loomade keele mõistmine);

- ebaharilik tugevus;

- ülesanne ja selle täitmine (nt tuua hiiglase kolm kuldset juuksekarva, et printsess

vabastada);

- truud sugulased (nt tädi, vanaema);

- kurjad sugulased (nt abikaasa sugulased, võõrasema);

- ülivõimed (nt võime näha peidetud esemeid, ükskõik kus nad ka pole, avada ja lukustada kõik lukud);

- kolm sfääri (taevas, maa ja põrgu). 
Juttudes esinevate koletiste ülesandeks on illustreerida hea võitu kurja üle või mineviku ebaõigluse vastu protesteerida. Samuti on kõik asjad muinasjuttudes panoraamsed: nad on kas romantilised, kujutletamatud, naljakad, veidrad või siis kohalikel traditsioonidel põhinevad.

\section{Universaalsus ja paralleelsus muinasjuttudes}

Olematu maailma loomine reaalse elu põhjal ei ole ühegi regiooni eripärane paradigma, sest muinasjuttude peajooned langevad kõikjal ühte. Vaatamata variatsioonidele ja kohalikele iseärasustele on kõigil maailma muinasjuttudel ühine muster. Kogu maailmas teatakse jutte inimkonna tekkest ja päritolust ning loomajutte mõne looma, näiteks Üaakali kavalusest, varese üleannetusest ja tiigri kuninglikust suuremeelsusest. Seitsme vennaga õde, teise naise kadedus, koletise kuritahtlikkus, teadlase lihtsameelsus, hea ja vooruse ülim võit, õnn pärast paljusid katsumusi, muresid ja puudust - need on vaid mõned India erinevate paikkondade ja kogu maailma muinasjuttude ühisjoontest (Chaudhury 1994).

Eri regioonide muinasjuttude sarnasusi märkasid esmakordselt kultuurilise evolutsiooni teoreetikud Tylor ja Lang. Nad lõid üheaegse tekke teooria, millega seletati mitmete kultuurinähtuste paralleelset ja samaaegset arengut erinevais ühiskondades. Aega ja geograafilisi piire ületav transtsendentne inimvaim tundus kõige loogilisem alus seletamaks taolisi sarnasusi eri maade rahvajuttude vahel. Inimvaimu ühtsus avaldub sarnastes sotsiokultuurilistes olukordades üksikisikute vastuses teda ümbritsevale keskkonnale (Prasad 1989).

\section{Mitteverbaalsed teated rahvajuttudes}

Üldiselt kasutatakse muinasjuttudes peidetud tagamõtet ja kaudset viitamist. Muinasjutu mõju oleneb sellest tagamõttest. Kui kirjasõnast õppimine polnud veel nii levinud, olid peidetud moraali ja õpetusega muinasjutud Indias isikliku arengu edendajate ja sotsialiseerijate rollis; kõige ilmekamad näited sellistest tekstidest on ehk Pant Üatantra ja Fatak Katha. Mõned tavalisemad muinasjuttudes esinevad moraalid on:

- hea võidab ja kuri saab karistada;

- igaüks saab, mida väärib;

- tõde tuleb päevavalgele;

- heateole vastatakse heaga;

- suur tükk ajab suu lõhki;

- sõpra tunned hädas;

- ahnus ajab upakile;

- halvast ei tule head;

- kel võim sel vägi.

Jutud sisaldavad hoiatusi, nt valitsejatele (maskeeritud talupoeg tapab kuninga, rott või jänes võidab elevandi või tiigri) ning on olulised traditsioonide alalhoidmiseks ja teatud tabude rõhutamiseks.

Järgnevalt on esitatud mõningad Bihari jutud koos kommentaaridega nende sisu, tegelaskujude, isikutevaheliste suhete jm kohta. 


\section{Bawan Ganga}

Elas kord vaene alama kasti mees, kes end vaevu ära elatas juhuslike põllutööde ja seakasvatamisega. Sel mehel oli tütar, kelle kohuseks oli sigu väljale ajada.

Ühel täiskuu päeval, tähtsa peo päeval, oli tüdruk sigu karjatamas ning nägi noort braahmanit mööda kiirustamas. Tüdruk uudishimutses, mis põhjusel too peaaegu jooksis. Braahman vastas, et ta tahab jõuda Gangese jõeni, et seal kümmelda, kuni veel täiskuu kestab. Tüdruk naeratas ja ütles talle, et kuna Gangeseni on palju maad, siis ta vaevalt sinna jõuab, kuid et ta võib noormeest tema hädas aidata. Braahman tahtis teada, kuidas teda saab aidata. Tüdruk osutas räpasele lombile, kus sead püherdasid, ning ütles, et kui noormehe südames on tõeline usk ja kui ta tõesti usub temasse, sukeldugu lompi ning tüdruk kutsub esile täiskuu kõige õnnelikuma hetke, nii et noormees saaks tasutud, nagu oleks ta Gangeses kümmelnud.

Braahman sukelduski lompi, leidis selle põhja juveele täis olevat ja tõi peotäie neid kaasa. Tüdruk soovitas tal veel kord sukelduda seekord oli põhjas vaid muda. Siis ütles tüdruk talle, et need juveelid olid tasuks ta usu eest. Üllatunud braahman oli tüdrukust sisse võetud ja kosis teda. Neiu punastas, kuid vastas naeratades, et ta ei või ilma oma isa nõusolekuta abielluda.

Noor braahman küsiski tüdruku isa nõusolekut, kuid too ei tahtnud soostuda tütre abieluga nii kõrgest kastist mehega. Keeldumine murdis noore braahmani südame ja ta ähvardas end ära tappa. Braahmani surma eest vastutamine hirmutas isa, nii et ta andiski vastumeelselt oma nõusoleku.

Peeti pulmad. Kui pruut ja peigmees lahkumas olid, tahtis isa neile kaasavara anda. Tüdruk andis salaja oma abikaasale nõu, et too küsiks teatud lehma, teatud sea ja teatud papagoi. Vaene mees oli oma väimehe soovist jahmunud, kuid pidi kingid üle andma. Pruut ja peigmees lahkusid külast.

Lehm oli Suravi ehk õnnelik lehm, kel oli palju piima. Siga oli kõigi selle maa sigade juht ja see papagoigi polnud tavaline lind - tal oli juurdepääs jumal Indra oukonnale, kust ta igal hommikul oma käskijannale uudiseid tõi.

Noor braahman ja ta naine elasid väga õnnelikult. Ühel päeval tõi papagoi tüdrukule teateid, et Indra oli otsustanud läheneval vihma-hooajal lasta sadada vaid Rajgiri paljastele nõlvadele ja mahajäetud orgudesse. Kõikjal pidi tulema nälg. Uudiseid kuuldes käskis tüdruk seal koos tolle alamatega kõik paljad nõlvad ja orud 
üles tuhnida. Seejärel palus ta oma lehmal väljasid väetada, ning seegi sai tehtud. Siis palus tüdruk oma abikaasal sinna riisi külvata. Braahmanist abikaasa oli üllatunud, kuid tegi siiski nii, nagu naine soovis. Mõne aja pärast, kui sadama hakkas, kasvas sinna palju riisi. Nad varustasid riisiga ka neid alasid, kus vili ikaldus.

Indra oli vihane, et tema plaan nälga esile kutsuda läbi kukkus. Ta andis rottide armeele käsu vili hävitada. Aga papagoi tõi uudised oma perenaisele ning braahman viis vilja valvama terve armee kasse, mispeale rotid põgenesid. Indra oli tulivihane ning kui riis oli lõigatud ning rehe all, käskis ta tõusta tormil, mis terad ära pidi puhuma. Jälle tõi papagoi oma perenaisele uudised ja see soovitas kaasal kaevata mäe jalamile sügava vallikraavi. Nii tehtigi. Tuli torm, kuid riis oli kraavis peidus. Niimoodi päästetigi terve riik näljast tänu tüdruku voorustele, kavalusele ja taibukusele.

Vallikraav on senimaani seal. Rajgiri lõuna-värava juures olev järv, kus varem sead püherdasid, sai nimeks Bawan Ganga ehk Viiskümmend Kaks Korda Võimsam Kui Ganges.

Bawan Ganga järv asub Rajgiri lähistel, Nalanda maakonnas ja eespool esitatud jutt on Rajgiri kandi rahva meelislugu. Rajgiris on iidsed varemed, seal on valitsenud paljud kuningad ja pühakud. Maaliline koht on tihedalt seotud budismi ja jainismiga ja tõmbab ligi palju külastajaid.

Esitatud jutt on keerukas ja mitmetahuline. Seal esitatakse Rajgiri tohutu kivimüüri tekkelugu, mis näitab püüdu juttu konkreetse kohaga siduda. Ühtlasi on tegemist looga, kus tavaline inimene on vastasseisus üleloomuliku olendiga. Inimene on alati ihaldanud kontrollida üleloomulikke jõude või vähemalt nendega suhelda. Selles jutus see õnnestubki. Siit leiame ka terve rea peidetud sõnumeid ja väärtushinnanguid:

1. tavaline inimene võib valitsejat võita, kui tal on õigus ja ta on kaval;

2. inimeste ettekujutuse kohaselt jaguneb maailm kolmeks - taevas, põrgu ja maa;

3. naispeategelane mõistab loomade keelt;

4. loomad ja linnud aitavad kooselu õnnele kaasa;

5. sotsiaalne norm nõuab, et tüdruk ei abielluks ilma isa nõusolekuta;

6. kastidevahelised abielud on küll harvad, kuid siiski olemas;

7. voorused ei ole kõrge kasti monopol. 


\section{Kinaver ja abielu}

Neli oraooni hõimu liiget olid lapsepõlvest peale suured sõbrad. Nad käisid samal tantsuplatsil tantsimas ja olid üksteisele sõprust vandunud.

Suureks kasvades valisid nad erinevad ametid. Üks neist käis majast majja kinaveri müües, teine hakkas kangruks, kolmas sõber valis puunikerdamise ning neljas hakkas kullassepaks.

Ükskord tuli neil mõte minna uusi paiku vaatama, tehes samal ajal töö. Nad võtsid oma tööriistad ja asusid teele.

Nad käisid paljudes kohtades. Kord tuli neil veeta öö mangopuude aias. Pärast sööki otsustati, et kuna nad on tundmatus kohas, oleks parem öö läbi kordamööda valvet pidada. Puunikerdaja oli esimene valvesolija, kuna teised end magama asutasid. Mõne aja pärast sai puunikerdajal niisama istumisest villand ning ta võttis tüki kuiva puud, millest voolis naise kuju. Ta pani kuju jalgadele ning äratas kullassepa tema valvekorraks.

Kullassepp tõusiski üles ning märkas mõne aja pärast naisekuju. Ta mõtles: "See on kena neiu, kuid tal puudub ehe." Nii valmistaski ta kuldketi, mille kujule kaela ümber asetas. Ta sepistas kujule ka paari kõrvarõngaid ja käevõrusid. Siis äratas ta kangru ja läks ära magama. Ka kangur märkas puust naisekuju, imetles selle figuuri ja mõtles: "Miski on puudu. Ahjaa, ta peaks sari kandma." Kohe võttis ta lõimed üles ja kudus sari valmis. Hellalt mähkis ta kuju sarisse. Siis äratas ta kinaverimüüja ja heitis magama sõnadega: "Sinu kord, vennas, olla valves." Ka kinaverimüüja nägi valves olles puust naist ja salvis ta laupa päevatõusul kinaveriga. Puust naine ärkas ellu ja seal seisis kena häbelik neiu.

Neli sõpra hakkasid vaidlema selle üle, kes peaks tüdrukuga abielluma. Puunikerdaja ütles, et kui tema poleks tüdrukule kuju andnud, oleks ta puutükiks jäänudki. Kullassepp nõudis teda endale, kuna tüdruk kandis tema antud ehteid. Kangur väitis: "Mina andsin talle riided ja ta on minu." Kinaverimüüja kinnitas, et temal on tüdrukule kõige rohkem õigust.

Vaidlevad sõbrad nägid pühameest lähenemas ning tegid temast vahekohtuniku. Pühamees kuulas ära kõigi väited ning ütles: "See, kes ta valmistas on tema isa; see, kes ta riietas, on tema vanem vend; kes ehtis, on onu; kuid see, kes ta ellu äratas ja kinaveri laubale pani, on tema abikaasa."

Sõbrad kummardasid selle otsuse ees ning tüdrukust saigi kinaverimü̈̈ja naine. 
Jutt viitab tshotanagpuri hõimude seas levinud kombele sindur-daan, mille kohaselt tüdruk abiellub poisiga, kes ta laubale kinaveri määrib; jutt aitab seda kommet alal hoida.

Ka tänapäeval peetakse hõimuühiskondades sel moel kinnitatud abielusid kehtivaiks. Seda kommet kasutavad ära armunud; laatadel ilmub järsku poiss tüdruku ette ja salvib kinaveri talle laubale, mispeale tüdruku vanemad on sunnitud nad abiellunuiks kuulutama.

Jutust selgub ka, et tüdruku pärast võistlemine on India ühiskonnas alati tavaline olnud. Samas toetab see jutt vanasõna, et osav ei saa tegevuseta istuda. Kõigil neljal sõbral oli oskusi ning niisama istumise asemel eelistasid nad isegi öösel tööd teha ning nende töö kandis ka vilja.

\section{Kaks sõpra}

Elasid kord kaks suurt sõpra, kel mõlemal olid üleloomulikud oskused. Üks suutis riisi kvaliteeti hinnata ja teine inimeste iseloomu hinnata. Nad asusid koos pikale teele, et maailma tundma oppida. Nad käisid paljudes väikestes külades ja saabusid siis ühte suurde külla, kus elas radzha. Nad läksid radzha oukonda, kus neid külalislahkelt vastu võeti ning paluti külla jääda. Nad nõustusid, kuid kui riisi serveeriti, keeldus söömast see sõber, kes riisi headust hinnata suutis. Teine sõber keeldus köögivilju söömast. Sellest anti teada radzhale, kes kombe kohaselt tahtis ise nende sööki süüa. Nad ütlesid, et nende keeldumisel oli põhjus. Radzha palus neid: "Palun öelge, miks te keeldute söömast."

Seepeale ütles esimene mees: "Oo isand radzha, mulle serveeritud riis kasvas maal, kus kunagi surnuid põletati. Ma tunnen põlenud kehade ja puu lõhna." Siis pöördus radzha teise mehe poole ja küsis temalt keeldumise põhjust, lisades, et ta enda tütar oli need köögiviljad keetnud. Teine mees vastas: "Oo radzha, ma väga vabandan, kui ma ebaviisakas olen. Kuid sinu tütre hingeõhk on jäänud köögiviljadele külge. Toidul on tugev kitsepiima lõhn." Radzha saatis kohe amme järele, et tõtt teada saada.

Siis tuli tagasi varem välja saadetud mees ning rääkis radzhale, et kolmekümne aasta eest oli seal maalapp, mida surnukehade põletamiseks kasutati. Sestsaadik on seal riisi kasvatatud ning ka see riis on sealt pärit. Ka amm tunnistas, et kuna tal piisavalt piima polnud, oli ta radzha tütrele kitsepiima jootnud.

Saades teada, et mõlemal külalisel oli õigus olnud ning et neil on üleloomulikud võimed, veenis radzha neid oma õukonda jääma. Sõbrad võtsid selle ettepaneku vastu ning elasid sestpeale radzha oukonnas. 
Jutt on mitmetahuline ning selle võib liigitada lugude hulka, mis kõnelevad üleloomulikest võimetest. Kui tänapäeval keegi väidaks, et tal sellised võimed on, ei usutaks teda, kuigi muinasjuttudes toimuvat kiputakse tõeseks pidama.

\section{Kokkuvõte}

Muinasjutud nagu muudki folklooriliigid kujutavad inimeste tundeid, vajadusi, konflikte ja muid inimhinge aspekte, mida kujundab teatud kultuuris üleskasvamine. Muinasjutud on arvatavasti üks kõige selgemaid ja kohasemaid inimmõtete väljendajaid. Kindlas ühiskonnas domineerivate rahvajuttude uurimine aitab mõista nii ühiseid ja universaalseid kui ka sellele ühiskonnale omaseid jooni.

Käesolev artikkel püüdis tutvustada mõningaid Bihari populaarseid rahvajutte.

\section{Kasutatud kirjandus}

Chaudhury, P. C. 1994. Folktales of Bihar. New Delhi.

Chettiar, S. M. L. L. 1973. Folklore of Tamil Nadu. New Delhi.

Dundes, Alan 1989. Folklore Matters 'Knoxvitte'. Tennessee.

Prasad, D. 1989. Lok Sahitaya Aur Sanskriti. Allahabad.

Thompson, Stith 1946. The Folktale. New York. 